\title{
MATING BEHAVIOUR OF THE SIDE-BLOTCHED LIZARDS OF THE GENUS UTA (SAURIA: IGUANDIDAE)
}

\author{
BY GARY W. FERGUSON* \\ Museum of Zoology, University of Michigan, Ann Arbor, Michigan 48104
}

Since the monograph of Noble \& Bradley (1933) few investigators have studied the courtship of lizards in detail (see Milstead 1967 for literature reviews). To my knowledge no one has described quantitatively the courtship of any lizard species and attempted to analyse geographic variation.

Ferguson (1966) described the general courtship procedure of the side-blotched lizard Uta stansburiana from West Texas. My major goals were: (1) to describe more quantitatively various features of the mating behaviour of lizards of this genus; (2) to include in the analysis individuals from several geographic localities; (3) to evaluate the behavioural features as taxonomic characters; (4) to obtain insight into the adaptive significance of these features; (5) to obtain insight into the factors reponsible for evolutionary divergence of the features between populations.

\section{Methods}

In August 1966, and the summer of 1967, I photographed in slow motion the mating behaviour of forty-one pairs of $U$. stansburiana from four localities and eight pairs of Uta squamata from a single locality, Santa Catalina Island. I used a Bolex-H-16 mm movie camera with a Vario Zweiter $80 \mathrm{~mm}$ zoom lens. The camera speed averaged thirty-eight frames per $\mathrm{s}$ and the speed was checked periodically by photographing a running stop watch. I photographed most of the matings in the field, but I maintained the $U$. squamata singly in small terraria and photographed them in the laboratory. Although female utas occasionally performed stereotyped behaviour that seemed to indicate non-receptivity, their response to a courting male was usually passive. I did not analyse the behaviour of females in this study.

I photographed in mid-morning or late afternoon during the peak activity of the lizards. After photographing the behaviour, I recorded the cloacal temperature of most individuals with a Schultheis thermometer. The maximum difference in mean temperature between any two populations was $1 \cdot 1^{\circ} \mathrm{C}$. All temperature means

*Present address: Division of Biological Sciences, Kansas State University, Manhattan, Kansas 66502. fell within the ranges observed during normal activity of this species (Cowles \& Bogert 1944) and the probability that the temperature differences markedly affected the behaviour seemed to be small. The following represents the number of courting pairs photographed from each locality and the mean cloacal temperature of the courting males from that locality:

twelve pairs from Kermit Texas: $36 \cdot 1{ }^{\circ} \mathrm{C}$;

thirteen pairs from Fruita, Colorado: $35 \cdot 5^{\circ} \mathrm{C}$; ten pairs from Pyramid Lake, Nevada: $35 \cdot 6^{\circ} \mathrm{C}$; eleven pairs from Victorville, California: $35.0^{\circ} \mathrm{C}$;

eight pairs from Santa Catalina Island: no temperatures taken.

I presented male lizards discovered in the field or maintained singly in terraria with a nonresident female in order to stimulate mating behaviour. In the field each non-resident female was restrained with a fishing line harness in order to prevent her from hiding from the male.

I used a Vanguard M-16c, s-13 motion analyser to project the film frame by frame and at slow speeds. From this I was able to determine the form of various features of the mating behaviour and calculate the duration of these features by counting the total number of frames exposed at a known camera speed.

In considering twelve taxonomic characters of Uta mating behaviour (Table I), I used MannWhitney $U$ and Fisher Exact Probability tests (Siegel 1956) to test the significance of differences in character states between populations (Table II).

\section{Results}

One can divide successful mating behaviour of a male uta into four stages: approaching, licking, neckholding, and copulating (Fig. $1 \mathrm{~A}, \mathrm{i}$-iv). The following discussion generalizes the variation observed in all populations, and concerns successful mating only. Several features varied geographically (Fig. 2; Tables I and II).

Approaching. A male often performs an aggressive display before he begins to approach a female. This display includes arching his back, compressing his body laterally, expanding his throat, and performing a series of push-up 
Table I. Character States of the Mating Behaviour of Uta

\begin{tabular}{|c|c|c|c|c|c|c|}
\hline $\begin{array}{l}\text { Character } \\
\text { description }\end{array}$ & $\begin{array}{l}\text { Character } \\
\text { no. }\end{array}$ & $\begin{array}{l}\text { Kermit, } \\
\text { Texas }\end{array}$ & $\underset{\text { Fruita, }}{\mathbf{X}+}$ & $\begin{array}{l}\text { S.D. } \\
\text { Pyramid } \\
\text { Lake, } \\
\text { Nevada }\end{array}$ & $\begin{array}{l}\text { Victorville, } \\
\text { California } \\
\text { I }\end{array}$ & $\begin{array}{l}\text { Santa } \\
\text { Catalina } \\
\text { Island, Gulf } \\
\text { of California }\end{array}$ \\
\hline $\begin{array}{l}\text { Per cent males that circle female once or twice } \\
\text { when approaching }\end{array}$ & 1 & $\begin{array}{c}80 \\
(10)\end{array}$ & $\begin{array}{c}20 \\
(10)\end{array}$ & $\begin{array}{l}13 \\
(8)\end{array}$ & $\begin{array}{c}09 \\
(11)\end{array}$ & $\begin{array}{l}13 \\
(8)\end{array}$ \\
\hline Mean duration of the approach in $s$ & 2 & $16 \underset{(9)}{ \pm} 9$ & $\underset{(10)}{07 \pm 8}$ & $05 \underset{(8)}{ \pm} 8$ & $07 \underset{(7)}{ \pm}$ & $03 \pm 1$ \\
\hline $\begin{array}{l}\text { Per cent of males that performed shudder sequences } \\
\text { during the approach and/or lick stage }\end{array}$ & 3 & $\begin{array}{c}90 \\
(10)\end{array}$ & $\begin{array}{c}91 \\
(11)\end{array}$ & $\begin{array}{l}22 \\
(9)\end{array}$ & $\begin{array}{l}74 \\
(8)\end{array}$ & $\begin{array}{c}100 \\
(8)\end{array}$ \\
\hline $\begin{array}{l}\text { Per cent of males that interrupted lick stage to } \\
\text { re-approach }\end{array}$ & 4 & $\begin{array}{c}0 \\
(10)\end{array}$ & $\begin{array}{l}65 \\
(11)\end{array}$ & $\begin{array}{c}0 \\
(10)\end{array}$ & $\begin{array}{l}25 \\
(8)\end{array}$ & $\begin{array}{l}25 \\
(8)\end{array}$ \\
\hline Mean number of times that male licked the female & 5 & $17 \underset{(10)}{ \pm} 09$ & $23 \underset{(9)}{ \pm}$ & $07 \underset{(6)}{ \pm 04}$ & $08 \underset{(7)}{ \pm 10}$ & $\begin{array}{c}17 \pm 07 \\
(8)\end{array}$ \\
\hline Mean duration of lick stage in s & 6 & $23 \pm \underset{(9)}{ \pm 10}$ & $33 \underset{(9)}{ \pm 15}$ & $07 \underset{(6)}{ \pm 07}$ & $13 \pm \underset{(7)}{ \pm 17}$ & $27 \pm 11$ \\
\hline $\begin{array}{l}\text { Ratio of shudder units to each other: } \\
\text { first unit of shudder sequence longer than sub- } \\
\text { sequent units in shudder of some individuals }= \\
1 \text {, shudder units always of uniform duration }=0\end{array}$ & 7 & $\mathbf{0}$ & 1 & & 1 & 1 \\
\hline $\begin{array}{l}\text { Per cent of males that shift their forefeet several } \\
\text { times without changing their body position relative } \\
\text { to that of the female }\end{array}$ & 8 & $\begin{array}{c}10 \\
(10)\end{array}$ & $\begin{array}{r}89 \\
(10)\end{array}$ & $\begin{array}{l}17 \\
(6)\end{array}$ & $\begin{array}{l}50 \\
(4)\end{array}$ & $\begin{array}{r}0 \\
(8)\end{array}$ \\
\hline $\begin{array}{l}\text { Occurrence of neck nipping: } \\
\text { nipping neck or shoulder region of female before } \\
\text { taking hold of neck }=1 \text {, } \\
\text { males never nipped neck or shoulder region of } \\
\text { female before taking hold }=0\end{array}$ & 9 & 0 & 0 & $\mathbf{0}$ & 0 & 1 \\
\hline $\begin{array}{l}\text { Occurrence of female swinging: } \\
\text { male swings female from side to side after taking } \\
\text { neck hold }=1 \text {, male does not swing female from } \\
\text { side to side after taking neck hold }=0\end{array}$ & 10 & 0 & 1 & 1 & 1 & 1 \\
\hline $\begin{array}{l}\text { Occurrence of head jerks: } \\
\text { male jerks head spasmodically if female moves } \\
\text { after ejaculatory thrusts }=1 \text {, males never } \\
\text { perform this behaviour }=0\end{array}$ & 11 & 0 & 1 & 1 & 1 & 0 \\
\hline Mean duration of copulation in s & 12 & $13 \underset{(12)}{ \pm} 06$ & $\begin{array}{c}76 \pm 81 \\
\text { (13) }\end{array}$ & $54 \underset{(7)}{ \pm 27}$ & $160 \underset{(4)}{ \pm 69}$ & $\frac{12 \pm 05}{(7)}$ \\
\hline Mean number of ejaculatory thrusts & 13 & $04 \underset{(10)}{ \pm 01}$ & $19 \underset{(11)}{ \pm 06}$ & $11 \underset{(7)}{ \pm 02}$ & $26 \underset{(4)}{ \pm 11}$ & $05 \underset{(7)}{ \pm 02}$ \\
\hline
\end{tabular}

sequences (Figs. 1B and 3). Following this, some males rush toward the female without pausing and bite her flank vigorously. Such a male releases the flank hold after a few seconds, takes a neck hold, and completes the mating sequence without performing the lick stage. However, most males approach the female more slowly and usually relax the aggressive posture (arch- ing and lateral compression) during the approach. During the slower approaches, most males pause one to eight times to perform one or two push-up sequences or to perform another bobbing movement called the 'shudder'. The 'shudder' is probably synonymous with 'courtship nod' of Carpenter (1962).

The shudder sequence differs from the push- 
Table II. Matrices of Significant Differences for Several Characters of the Mating Behaviour of Uta

Character 1

$\begin{array}{lllll}\mathrm{T} & \mathrm{C} & \mathrm{N} & \mathrm{M} & \mathrm{SC}\end{array}$

Texas

Colorado

Nevada

Mojave

Texas

Colorado

Nevada

Mojave

Texas

Colorado

Nevada

Mojave

Texas

Colorado

Nevada

Mojave

Texas

Colorado

Nevada

Mojave

Character 3

$$
\begin{array}{lllll}
T & C & N & M & \text { SC }
\end{array}
$$

Character 5

$\begin{array}{lllll}\mathbf{T} & \mathbf{C} & \mathbf{N} & \mathbf{M} & \mathrm{SC}\end{array}$

Character 8

$\begin{array}{lllll}\text { T } & \mathrm{C} & \mathrm{N} & \mathrm{M} & \mathrm{SC}\end{array}$

Character 13

T $\quad$ C N N M SC

\section{Character 2}

$\begin{array}{cccccc} & \text { T } & \text { C } & \text { N } & \text { M } & \text { SC } \\ \text { T } & & + & + & - & + \\ \mathbf{C} & & & - & - & - \\ \mathbf{N} & & & & - & - \\ \mathbf{M} & & & & & -\end{array}$

Character 4

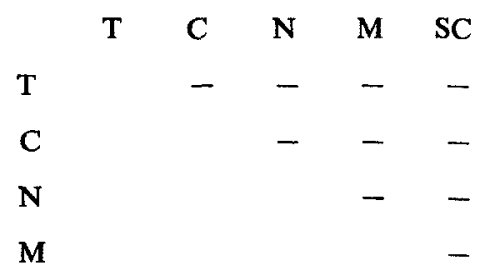

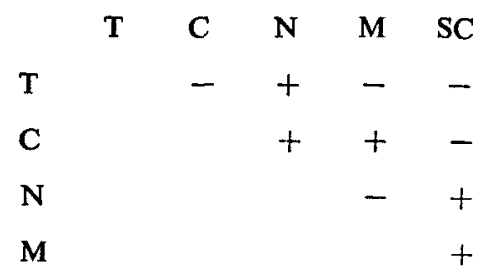

$\begin{array}{llllll} & \mathbf{T} & \mathbf{C} & \mathbf{N} & \mathbf{M} & \mathrm{SC} \\ \mathbf{T} & & + & + & + & - \\ \mathbf{C} & & & - & - & + \\ \mathbf{N} & & & & + & + \\ \mathbf{M} & & & & & +\end{array}$

Plus $=\boldsymbol{P}<0.05 ;$ Minus $=\boldsymbol{P}>0.05$ that differences are due to chance.

up sequence in several respects. First, during the shudder, a male seems to move only his head up and down. During a push-up a male moves his entire body up and down by holding his neck rigidly, using his hindquarters for a pivot, and flexing and extending his forelimbs. Second, lizards perform shudder sequences but not push-up sequences during locomotion. Third, 
A
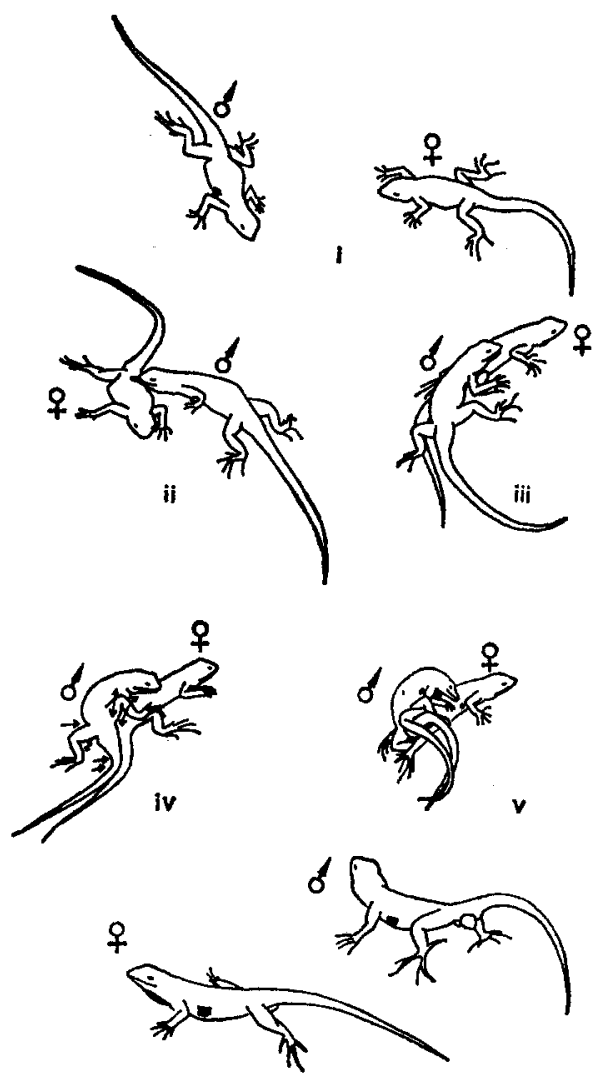

vi

B

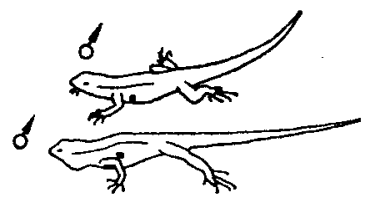

Fig. 1. Stages of mating (Ai-vi) and aggression (B) in Uta. Ai Approaching. Aii Licking. Aiii Neck-holding. Aiv and Av Copulating. Avi Uncoupling. B, Normal (top) versus aggressive (bottom) posture of two males interacting in the field.

each shudder sequence of a given individual contains an unpredictable number of units (2 to 27) usually of equal duration and height, whereas, each push-up sequence contains a stereotyped number of units of unequal duration and height. The first unit in some shudder sequences of some individuals is longer and higher than the following units (Fig. 3). Fourth, the shudder sequence is normally confined to

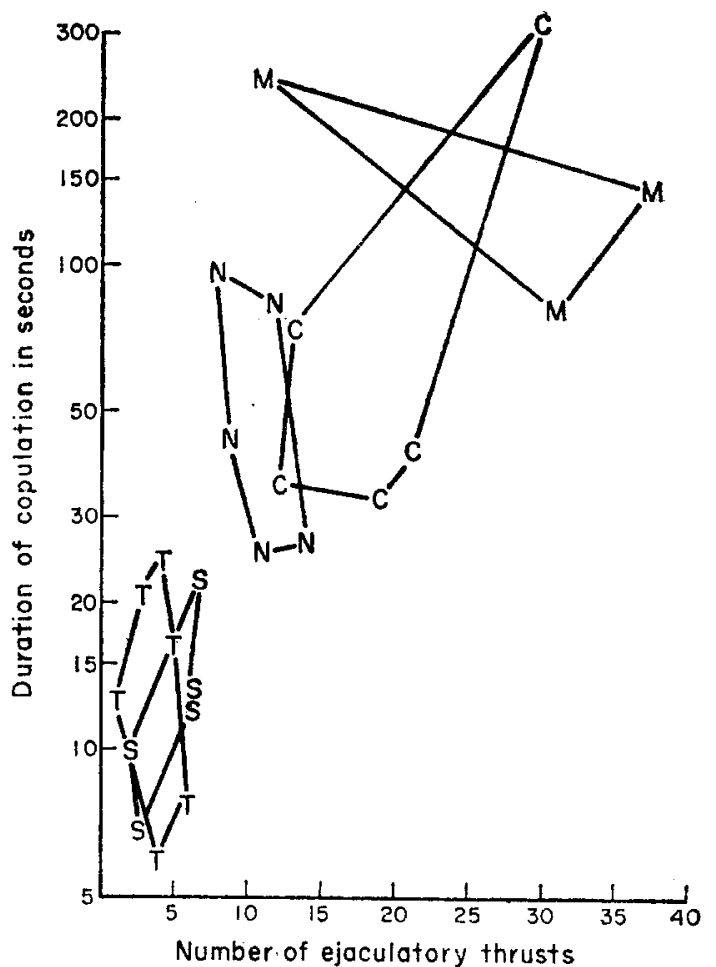

Fig. 2. Number of ejaculatory thrusts versus duration of copulation. $\mathrm{T}=$ Texas utas. $\mathrm{S}=$ Santa Catalina Island utas. $\mathbf{M}=$ Mojave utas. $\mathbf{N}=$ Nevada utas. $\mathbf{C}=$ Colorado utas. Each symbol represents the outermost of the scatter of points for that population. Note the short copulation and low number of ejaculatory thrust of the Texas and Santa Catalina Island utas.

heterosexual encounters, while the push-sequence occurs in several social and asocial contacts.

The pauses between licks vary from 0.3 to more than $10 \mathrm{~s}$ in duration. In most populations, push-ups displays are performed only during pauses greater than or equal to $1.0 \mathrm{~s}$.

The pathway of the approach varies. In most populations a male approaches the female in more or less a straight line until his head is next to her pelvic region (Fig. 1A,i). If he approaches from in front of the female, he usually passes parallel to her and a few $\mathrm{cm}$ away from her. When he reaches the level of her pelvic region, he turns, approaches her pelvic region directly, and sometimes performs a long shudder sequence. Occasionally, males circle behind the female and approach her pelvic region from the side opposite to that approached originally. Males rarely contact the anterior region of the female initially. Males from Texas population ritualistically circle the female one or two times 


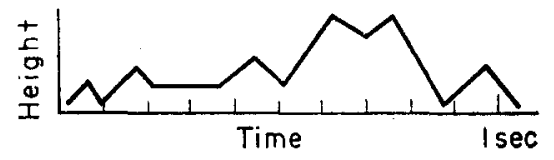

A Push-up sequence

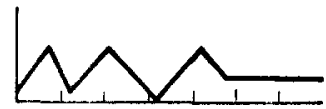

B 3 unit shudder sequence with uriform units

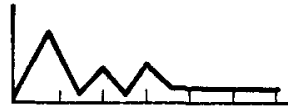

C 3 unit shudder sequence with non uniform units

Fig. 3. Display Action Pattern (DAP) Graphs (originally used by Carpenter \& Grubitz 1961, to illustrate push-up displays) of push-up and shudder sequences of the Santa Catalina Island Uta. Ordinate represents height. Abscissa represents time calibrated in tenths of an s. A. Push-up sequence. B. 3 unit shudder sequence with uniform units. C. 3 unit shudder sequence with non-uniform units.

before they approach her pelvic region. These circles are from 10 to $15 \mathrm{~cm}$ in diameter.

The duration of the last $30 \mathrm{~cm}$ of the approach of the male ranges from 1 to over $30 \mathrm{~s}$ and is correlated with the number and duration of pauses and circles.

Licking stage. After arriving at the pelvic region of the female, most males begin to lick this region (Fig. 1A,ii). Initially, a male licks her tail, hind legs and pelvic region a few times; then he moves anteriorily and licks her middorsal region; then he moves anteriorly again and licks her neck and shoulder region and finally obtains a neck-hold with his jaws on the loose skin of her neck and shoulder. Some males lick several times, pause, crawl to the other side of the female or even circle the female, lick a few more times and crawl to the original side again. The number of licks varies from three to forty.

During the lick stage most individuals perform both push-up and shudder sequences. The time and sequential relationships between lick, shudder, and push-up vary considerably. Some individuals lick two or three times in rapid succession (licks about 0.3 to $0.9 \mathrm{~s}$ apart), perform a longer shudder sequence and/or one or two push-up sequences during the pause, and then repeat the rapid series of lick-shudders. Other individuals lick at a more uniform rate (licks 0.9 to $1.5 \mathrm{~s}$ apart), perform push-up or shudder sequences between practically every lick and only occasionally pause for periods longer than $3 \mathrm{~s}$. Usually, the shudder sequences are concentrated in the first part of the lick stage, whereas the push-up sequences are distributed more randomly throughout that stage. Some individuals perform few or no push-up and/or shudder sequences during the lick stage.

Males shift the position of their forefeet several times during the lick stage. Some males shift their forefeet only when they move their body forward to lick on a more anterior region of the female. Other males shift their forefeet several times between moves forward. The total duration of the lick stage ranges from 2 to more than $70 \mathrm{~s}$.

Neck-holding stage. After obtaining the neck or shoulder hold, a male usually performs one or more push-up sequences, pauses (from a few $s$ to several $\mathrm{min}$ ), and sometimes crawls forward dragging the female. Before attempting to copulate, the male frequently lifts the anterior portion of the female from the ground and pulls her head and shoulders first to one side and then to the other. This causes the anterior part of her body to swing in an arc from side to side like an automobile windshield wiper. From one to several arcs $(0.5$ to $1.0 \mathrm{~s}$ per arc) are either performed in rapid sequence or interspersed with pauses. Finally, a male drapes one hind leg across the pelvic region, begins to move the 
leg back and forth in stroking motion and simultaneously begins to push the base of his tail against hers (Fig. 1A,iii and iv). The stroking behaviour of the male causes the pelvic region of the female to bow upward, the base of her tail to raise and the lips of her cloaca to spread. The male immediately slips his tail under that of the female and opposes his cloaca to hers (Fig. 1A,v).

Copulating. A male usually pushes his cloacal region forward rapidly several times before his hemipenis is completely inserted with a final more definitive thrust; after a $1 \mathrm{~s}$ pause, his tail jerks forward spasmodically several times ( 1 to 37 at a rate of one jerk each s). Presumably these jerks are ejaculatory thrusts. There is always a pause between the last tail jerk and the uncoupling. Sometimes the tail of the male seems to pulsate back and forth weakly during the pause. Occasionally the female begins to crawl forward before uncoupling begins. Some males immediately respond to this movement with a curious 'head jerk' behaviour. To perform this behaviour a male rapidly rocks his head from side to side in a jerky fashion ( 3 to 6 jerks per $s$ ) for as long as $15 \mathrm{~s}$. The female always stops moving when the head jerk begins. Uncoupling is rapid; the male backs off the female, his back arched and his hemipenis still everted (Fig. 1A, vi). After a brief pause during which his hemipenis is retracted and his tail lowered, he begins to crawl a few $\mathrm{cm}$ and remains quiescent. The total duration of copulation is from 5 to $245 \mathrm{~s}$.

\section{Discussion}

I noted several geographic differences in the features of the mating behaviour (Fig. 2; Tables I, II). In the following discussion I assume that these differences are heritable.

Some characters of the male courtship behaviour supported the distinctiveness of previously defined groups of Uta. For example, the distributions of the states of five characters (Table I, numbered $3,5,6,8$, and 13) differed significantly between Nevada Uta (U. s. nevadensis) and Colorado Uta (U. s. stansburian, Table II). The distribution of the states of two characters (Table I, numbers 1 and 10) of the Texas Uta (U. s. steinegeri) differed from those of all other populations studied (Table II). However, none of these character state differences are distinct enough to be diagnostic.

The characters of the courtship behaviour may have limited phylogenetic value. For example, the Texas and Santa Catalina Uta resemble each other but differ from the other three populations in the states of three characters (Tables I and II, numbers 11, 12, and 13). This similarity parallels the overall morphological similarity demonstrated by Ballinger \& Tinkle (in preparation). They suggest that these two populations had a common ancestor distributed throughout the southwest during an interglacial period.

Indirect evidence suggests that Texas utas are more aggressive than Colorado utas, e.g. greater dispersion of Texas utas and greater intensity of aggressiveness directed by resident Texas utas to non-residents (Tinkle 1967, pp. 159-161).

Tinkle argued that selection for aggression might be stronger in the Texas population than in the Colorado population because Texas utas are short-lived and have only one chance to reproduce. Successful males must aggressively defend a territory during their first breeding season. Conversely, Colorado utas more frequently survive at least two breeding seasons. By being submissive a yearling Colorado uta can share a favourable territory with a dominant second year uta. Such a submissive yearling would have a better chance of surviving to a second breeding season than a more aggressive yearling that is forced to set up a territory in a less favourable area. The submissive yearling probably would remain in the favourable area and dominate it during his second breeding season. Thus, selection would favour strongly any genes for submissiveness.

One function of courtship behaviour may be to pacify the female so that she will allow copulation (Bastock 1967). Two of the features of Uta courtship, circling and licking, probably serve this function. Both features are highly ritualized in some Uta populations. Circling behaviour in various animals might have first appeared as compromise behaviour (Hinde 1966 , p. 277) during approach-avoidance conflict situations. That males from some Uta populations in which circling behaviour is rare occasionally circled an unusually aggressive female, supports this hypothesis. Licking behaviour might have originated in either a chemoreceptive or tactual context and may still serve both functions to some degree in utas. However, both circling and licking seem to pacify receptive females. One might expect these two features to be better developed in males from populations that contain more aggressive females.

The duration of copulation might alșo bẹ 
modified by the degree of intra-specific aggression. If the probability of being aggressively molested during copulation by a conspecific is higher because conspecifics are more aggressive, then selection would favour shorter copulation in that population. Both Hunsaker (1962) and Noble \& Bradley (1933) observed a second male spiny lizard challenge and aggressively interfere with a courting pair in the laboratory. I observed a second female uta interfere with a courting pair in the field in Texas. In short, there seem to be three adaptations to intraspecific aggression in the courtship display of male utas: ritualized circling, ritualized licking and short copulation.

If the Texas utas are more aggressive, one would predict stronger selection for adaptations to aggression in the male courtship of the shortlived Texas utas. These adaptations seemed to be better developed in Texas utas than in Colorado utas (Table III). Nevada and California utas also ranked low in these presumed adaptations to aggression (Table III). The may be operating more strongly to reduce the duration and elaborateness of both the courtship and the push-up display in this population than in any other (see Ferguson 1969).

Other factors previously suggested to explain the divergence of the push-up display (character displacement, pleiotropy and secondary selection) should be considered as factors in the geographic divergence of the courtship display (Ferguson 1969).

\section{Summary}

I described four stages of the mating behaviour of Uta: approaching, licking, neck-holding, and copulating. Some aspects of mating behaviour are more stereotyped within Uta populations than between populations. However, none of the geographic differences are sufficiently great to be useful for subspecific diagnosis. Absence of 'head jerk' behaviour and short copulation may indicate ancestral affinity between Texas and Santa Catalina Island Uta. A higher degree of intraspecific aggression and shorter life

Table II. Degree of Development of Presumed Adaptations to Aggression in Mating Behaviour of Uta

\begin{tabular}{lcccc}
\hline \multicolumn{1}{c}{ Population } & $\begin{array}{c}\text { Ritualized } \\
\text { circling }\end{array}$ & $\begin{array}{c}\text { Relatively long } \\
\text { licking stage }\end{array}$ & $\begin{array}{c}\text { Relatively short } \\
\text { copulation }\end{array}$ & $\begin{array}{c}\text { Total number of } \\
\text { adaptations }\end{array}$ \\
\hline Texas & 1 & 1 & 1 & 3 \\
Colorado & 0 & 1 & 0 & 1 \\
Nevada & 0 & 0 & 0 & 0 \\
California & 0 & 0 & 0 & 0 \\
Santa Catalina & 0 & 1 & 1 & 2 \\
\hline
\end{tabular}

$1=$ well developed; $0=$ poorly developed.

proximity of individuals to each other in the field suggested that they were less aggressive than the more dispersed Texas utas. The longevity of utas from these populations is unknown; but this hypothesis predicts that they survive for more than one breeding season. Santa Catalina utas ranked relatively high in adaptations to aggression (Table III). The degree of aggression and longevity of utas from this population are also unknown; one would predict that they are more aggressive than utas from some populations and survive for only one breeding season.

The reduced lick stage of the Nevada and California utas is unique (see Tables I and II, character numbers 3,5 and 6). Predator selection expectancy in some Uta populations may be directly or indirectly responsible for the presence of circling behaviour, longer duration of the licking stage and the shorter duration of copulation in those populations.

\section{Acknowledgments}

This study constitutes part of a dissertation submitted in partial fulfillment of the requirements for a Ph.D. at The University of Michigan. I thank Charles O. McKinney for assisting in the field; J. S. Farris for offering statistical advice and writing a computer programme for statistical analysis of the data; Orlando Cuellar and Mario Baudoin for assisting in the field and serving as interpreters during trips to Mexico; Richard D. 
Alexander, Dale R. McCullough, Thomas E. Moore, and Charles F. Walker for serving on my doctoral committee and offering advice and criticism during the study. I thank many people including state and federal officials and private citizens of both the United States of America and Mexico for cooperating with me in obtaining access to government controlled property and permission to collect on this property. Included in this list are: Dr Rodolfo Hernandez Corzo of the Departmento de Conservacion de la Fauna Silvestre, La Cuidad, Mexico, E.U.M.; Paul Ellis and his staff of Colorado National Monument, Fruita, Colorado; Boris P. Jogoleff and his staff of Torrey Pines State Reserve, Del Mar, California; Don Manuel Dominguez Ojeda and the crew of the 'Santa Lydia'; the officials of the Pescadores de Guaymas, Guaymas, Sonora; Bryan Burrage; Don Hunsaker; Timothy Lawlor; T. Paul Maslin; Robert L. Packard and the Dept. of Biology, Texas Technological College, Lubbock, Texas. To all of these people I am deeply grateful.

Finally, I express gratitude to my wife, Janna, who typed parts of the manuscript and provided encouragement throughout the study and to Donald Tinkle who guided and inspired me throughout this work.

This research was supported in part by a grant from the National Science Foundation, GB-3366, to T. H. Hubbell, The University of Michigan, for research in Systematics and Evolutionary Biology; in part by two grants from the National Science Foundation to D. W. Tinkle, The University of Michigan, GB-5416, for research on the Systematics of Uta, GB-4396, for research on the Comparative Ecology of Uta; in part by a predoctoral fellowship from the National Institute of Health, 5-FI-GM-33, 571-(01-03).

\section{R E F E R N C E S}

Ballinger, R. E. \& Tinkle, D. W. A systematic and zoogeographic revision of the side-blotched lizards, genus Uta (Family Iguanidae). In preparation.

Bastock, M. (1967). Courtship: An Ethological Study. Chicago: Aldine.

Carpenter, C. C. (1962). Patterns of behavior in two Oklahoma lizards. Am. Midl. Nat., 67, 132-151.

Carpenter, C. C. \& Grubitz, III, G. (1961). Timemotion study of a lizard. Ecology, 42, 199-200.

Cowles, R. B. \& Bogert, C. M. (1944). A preliminary study of the thermal requirements of desert reptiles. Bull. Am. Mus. Nat. Hist., 83, 261-296.

Ferguson, G. W. (1966). Releasers of courtship and territorial behavior in the side-blotched lizard Uta stansburiana. Anim. Behav., 14, 89-92.

Ferguson, G. W. (1969). Geographic Variation and Evolution of Stereotyped Behavioral Patterns of the Side-Blotched Lizards of the Genus Uta (Iguanidae). Univ. of Michigan Ph.D. thesis.

Hinde, R. A. (1966), Aninal Behaviour. New York: McGraw-Hill.

Hunsaker, D. (1962). Ethological isolating mechanisms in the Sceloporus torquatus group of Lizards. Evolution, 16, 72-74.

Milstead, W. W. (1967). Lizard Ecology: A Symposium. Columbia, Mo.: Univ. of Missouri Press.

Noble, G. K. \& Bradley, H. T. (1933). The mating behaviour of lizards, its bearing on the theory of sexual selection. Ann. N.Y. Acad. Sci., 35, 25-100.

Siegel, S. (1956). Non-parametric Statistics for the Behavioral Sciences. New York: McGraw-Hill.

Tinkle, D. W. (1967). The life and demography of the side-blotched lizard, Uta stansburiana. Misc. Publ. Mus. of Zool., Univ. of Michigan, 132, 1-182.

(Received 17 April 1969; revised 16 September 1969; $M S$. number: A828) 